\title{
Sciendo
}

\section{The perception and attitude of the resident and tourists regarding the local public administration and the tourism phenomenon}

\begin{abstract}
Mădălina Nicoleta FRîNCULEASA, University Valahia of Târgoviște, Department of Geography, Faculty of Humanities, Romania madalina_chitescu@yahoo.com

Răzvan Ion CHIȚESCU,
\end{abstract} National University of Political Studies and Public Administration, Faculty of Public Administration, Romania razvanric@yahoo.com

\begin{abstract}
The dynamism of the tourism phenomenon in relation to interconditioning with the local administrative environment, through the generated effects, can constitute an element of favorability of the socio-economic development of community. At the same time, tourism development also generates many problems for host communities. Thus, the policy developed by the local public administration regarding the tourism phenomenon regards the creation and maintenance of a competitive space for the involved actors (residents, tourists, institutions of public and private administration) in order to manage and supply profitable tourist products in a socio-economic context sustainable. Analyzing the perception and attitude of the residents of Moroieni, Dâmbovița, and the tourists present in this area, the paper presents the results of a sociological research which establishes the role and involvement of the local public administration in the tourism phenomenon.
\end{abstract}

Keywords: tourism, residents and tourists'perception, local public administration, Moroieni

JEL Classification: Z32, R11.

\section{Introduction}

In the last decades, tourism has become a key element of Romania's socio-economic development. Sustainable tourism is defined by UNESCO as "tourism that respects locals and travelers, cultural heritage and the environment". The tourism process involves numerous material and human resources, being strongly anchored in the dynamics of society. Tourism planning is very important for its efficiency, and positive social, economic and ecological 
impacts occur only by developing strategies specific to each tourist area by "studying the motivational demand, the resources, in terms of their functionality in tourism and profitability in exploitation" (Erdeli and Gheorghilaş, 2006, 288). However, this planning is very sensitive to local people's needs and attitudes towards the rise of this phenomenon (Fredline and Faulkner 2000), and local public authorities play an important role as mediator in the relationship - local community - benefits - tourist - satisfaction. Simmons (1994) considered the local community very important in tourism planning because the impact of tourism is best perceived at its level, and locals are an essential element in the "hospitality atmosphere" of a destination, including the satisfaction of tourists. Thus, the identification of the attitudes of the residents and the evaluation of the results of the analysis of their perception on the tourism process specific to their area, through the involvement of the public authorities, can determine the exploitation opportunities, the problems that should be solved, meaning tracing the general directions regarding the efficient management of the tourism process.

Ap (1992), developing the conceptual framework of the Social Exchange Theory - if locals feel the benefits of tourism greater than investment/costs they support its expansion and consider perceptions signify the meaning attributed to an object while attitudes signify a person's continuing predisposition or action tendencies to some objects.

The tourist represents the central factor of the analyzed process. Its presence in relation to the local community (citizens and authorities) conditions the other parameters and dictates the viability of the tourist destination. Thus, the analysis of its attitude and perception on the tourism phenomenon in a certain region can determine the way of efficient management of the tourism patrimony by the local public authorities in order to achieve the competitiveness of the proposed tourist destination.

Analyzing the perception of locals and tourists about the tourism phenomenon is a powerful tool in appreciating its quality and sustainable development. In the literature, this topic constantly appears, studies of a theoretical or empirical nature, focusing either on the socio-cultural and economic impact that this phenomenon has on local communities(Dogan, 1989; Brunt and Courtney, 1999; Wall and Mathieson, 2006; Gu and Wong, 2006;Sebastian and Rajagopalan, 2009;Suckall et al., 2009; Vargas-Sánchez et al., 2011; Diedrich and Garcia-Buades, 2009;Pehoiu et al., 2014; Brida et al., 2014),or on the impact on the environment, especially on the protected areas(Priskin, 2003; Alessa et al, 2003; Petrosilloet al., 2007; Van Winkle and MacKay, 2008; Ahmed, 2008; Ozturk et al, 2010; Dimitrakopoulos et al., 2010;Jones et al., 2011; Szell, 2012). 
Other approaches address the relationships between actors involved in the tourism process(Lankford and Howard, 1994; Liu et al., 2010, Del Chiappa\&Presenza, 2011; Presenza et al., 2012), and particular studies aim at comparing the opinions of different groups of residents(Besculides and colab., 2002 Andriotis and Vaughan, 2003).

The northern part of Dâmboviţa County is an area with a rich tourist potential, but the existence of a valuable tourist patrimony does not automatically lead to the manifestation of a profitable and sustainable tourism. An active and concerted involvement of the stakeholders of this destination (locals, tourists, public and private institutions, NGOs), by developing viable, flexible tourism products, perfectly anchored in the local reality, supported by the favorable legislative framework (National Development Plan 2007 -2013, the Master Plan for the Development of National Tourism 2007-2026) can lead to favorable economic and social outcomes. In this context, the town of Moroieni represents a conclusive case study on the issues addressed.

The main objective of the presented study is to identify the role and the extent to which the activity of the local public administration in an area with rich natural and anthropogenic potential has, in the view of local people and tourists, in the tourist process.

Research hypotheses:

1. The Moroieni locality is an area favorable to tourism development;

2. The development of sustainable tourism is a desideratum of local public administration;

3. Tourism increases the economic benefits of a locality, improves community infrastructure/superstructure systems and increases the quality of community life;

4. Local public authorities are actively involved in the tourism process.

\section{Methodology}

\subsection{Study area}

Moroieni is located in the north of Dâmboviţa County. Relief of the commune is represented by $53 \%$ of the mountain component dominated by the Bucegi Massif and $47 \%$ by the lalomita sub-Carpathian hills. The hydrographic network consists of the lalomiţa River, which forms from the waters from two glacier circles situated between the Ladies' Hill and the Countess's Columns of the 
Bucegi Mountains, and it's many tributaries. On the territory of the commune there are three reservoirs: Bolboci (91 ha), Scropoasa (6ha) and Dobreşti (1ha). The characteristic climate is mountain with alpine shades of over $1,800 \mathrm{~m}$ and subalpine, shelter, along the valley and depression basins. The climate is temperate. Vegetation and fauna includes elements specific to the Alpine floor (Bucegi Mountains) and subalpine which includes vegetation from the spruce family - larch, spruce. At lower altitudes vegetation is diversified by elm, birch and beech. In the forests of the mountain floor live: the deer, the stag, the lynx, the jar, the bear, the wild boar and the rooster, and in the lalomița river there is the trout. The specific soil is the weakly sandy and the brown of the forest.

The commune of Moroieni has a stable population of 5,241 residents distributed to its six villages: Moroieni, Lunca, Pucheni, Muscel, Glod, Dobreşti, with a commune residence in Moroieni. According to the age group structure, the active population is about $70 \%$.

The social infrastructure of the commune consists of: Kindergarten and Secondary School Ion CiorănescuMoroieni, MoroieniGlod School; Ion Ciorănescu Library, a Cultural House with a capacity of 250 seats, 5 cults: Peştera Monastery, $1000 \mathrm{~m}$ altitude Monastery, Church dedicated to the Holy Apostles Mihail and Gavril (Lunca), Church dedicated to the Assumption of the Holly Mary (Moroieni) Anton (Glod), Old Rite Orthodox Church - John Hozevitul and an Adventist Prayer House. Medical care is provided by three individual medical offices (two family doctor's and one dentist's cabinet) and a pharmacy point. An important medical center is the Tuberculosis Moroeni Sanatorium. The town also has a market in whose halls local people sell traditional products such as cheese and brandy, along with those with a varied utility. A fair with products from agrozoo-technical sphere is held weekly.

Transport infrastructure. The main road that crosses the commune from the south to the north is the National Road DN71 Târgovişte - Sinaia, which connects with the county seat (Târgovişte $-41 \mathrm{~km}$ ) and with the capital of the country (Bucharest - $119 \mathrm{~km}$ ). Locally, the connection with the village of Muscel is made on DC 147 Moroeni - Muscel $(8 \mathrm{~km})$, and Dobreşti village and the mountain area of the locality is made on DJ $130 \mathrm{Glod}$ - Cave (42 km).

The technical and municipal infrastructure is supported by the electricity, water and gas networks covering the entire locality. 


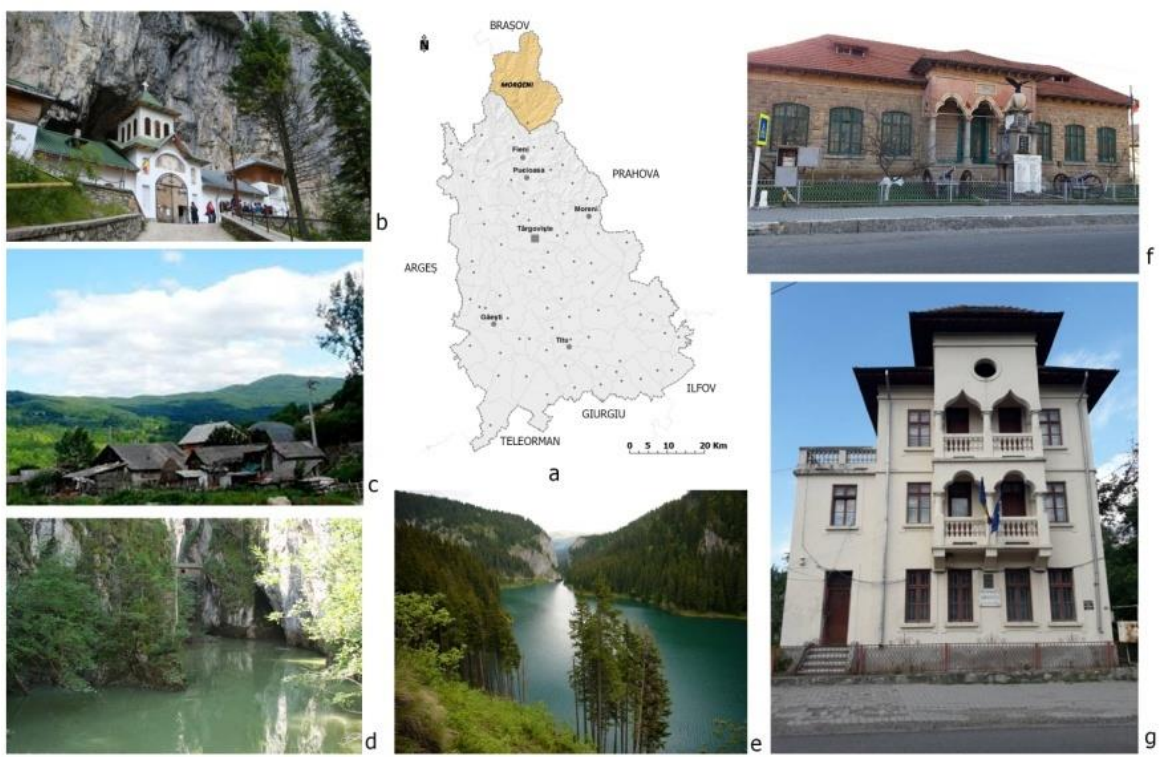

Figure 1. The geographical position of Moroieni in the Dâmbovița County. b. The Monastery of the Ialomita Cave; c. Muscel landscape; d. Scropoasa Lake. e. Bolboci Lake; f. The old school of Moroieni (1910); g. Ciorănescu Memorial House.

The town of Moroieni benefits from a rich natural and anthropic tourist heritage.

The natural heritage is the main source of tourist attraction, taking into account the fact that Bucegi Plateau and the higher course of river lalomita are on the territory of the locality. The most important tourist objectives (Chiţescu, 2003) are assigned to the Bucegi Natural Park - 16,334 ha on the territory of the locality (for example: Babele Plateau where the erosion forms are accompanied by a series of Alpine vegetal associations specific to Octopetaldryas, Primula minima, Saxifraga, Viola alpina, The Sphinx, Bears Keys, The Tartar' Keys, Keys of Zănoaga Keys, Orzei Keys, The Ialomicioara Cave, The Rătei Cave, The Omu Peak, protecting the alpine tundra reserves, Peat Bog Lăptici, Lespezi limestone quarry, elements of the glacial relief; paleontological, geological sites and endemic species). This area of Moroieni commune is defined by a special biodiversity and landscape value. Sub-Carpathian hills have natural elements with a distinct aesthetic visual impact.

In the village of Moroeni the cultural heritage includes the following elements with tourist potential: 1. architectural and historical monuments, category $A$ and $B$, dated from the 17th century to the 20th century, among which the important tourism potential are: Ciorănescu Memorial House, The old school of Moroeni, built in 1910; TBC Moroeni sanatorium; (built between 1936 and 1938 with a capacity of 605 seats, is the second largest in Europe and engages 
much of the surrounding workforce). It is remarkably mentioned in the novel The Alexandria Library by the writer PetreSălcudeanu in 1980, a volume awarded with the Writers and Romanian Academy Award; Anghelescu House; FloreaGurgu House; Gheorghe Chiţescu House; Dobreşti dam; GâlmaMoroeni Hydro Power Plant; Heroes Monument; Cultural House; 2. The cult objectives between which the Peştera Monastery is differentiated; 3. Traditional festivals: PADINAFEST; COLLECTION FESTIVAL, PADINA FOLK, MUSCEL CLOVERFEST; LIRA BUCEGILOR, along with sports activities and competitions, fairs and commemorative events.

The tourist patrimony is supported by an expanded accommodation structure and diversified services. Here is an important part of the tourist accommodation infrastructure of the county: 1 . Hotels -The Cave ( 3 stars) and Altitude 1000 (2 stars), Zanoaga Tourist Complex, Gâlma Hotel; cottages, villas and tourist cottages; Bungalow Complex TuristicZănoaga; Bolboci Tourist Cottage; Tourist Chalet Dichiu; Padina Tourist Cottage; Tourist Chalet Bridge with Flowers; Camping Zănoaga; Tourist Board Doina; Tourist Board Naparis; Tourist Board Octavian; Tourist Bed PiciorulBabelor; Tourist Board Heaven on the River; Tourist board ValeaŞipotului; Vila Coteanu; Villa Hanu with Ursi, Casa Moroieni, Maria Pension, Ferma Pension, Lin Guesthouse, Cabana ValeaCocorei, Pension D Oica; student camps (preserved) The deer, Hunter and the stag.

Most of them offer mass and entertainment services, combining the traditional local with the international one for a diverse range of tourists.

The tourism heritage is represented by: adventure tourism (Bucegi Natural Park - mountain climbing, mountain bike, speoturism), agrotourism (hostels in the village of Muscel and Moroeni); cultural tourism (numerous festivals, architectural heritage); ecotourism (visiting the Bucegi Natural Park); educational and scientific tourism (educational camps - English, computer science, sports, personal development, Bucegi Natural Park - reserves of scientific value), leisure and recreation tourism (leaving the city to relieve stress, fishing), Hobby-tourism or group), religious or pilgrimage tourism (churches and monasteries in the area).

\subsection{Methodological marks}

The research presented in this study took place between July-August 2017. These months were chosen because they represent the maximum flow of tourists in the area.The tool used was the questionnaire. This was done in such a way that the assumptions of the study could be verified. It includes 18 common questions and 4 questions that determine the respondent's profile. In the case of tourists, 319 questionnaires were applied, while for locals were 152 questionnaires. 
The hypothesis

Questions asked in the questionnaire

to be verified

Hypothesis $1 \quad$ 1. What do you think is the main tourist attraction of the locality?

2. What is the form of tourism that you practice in the area of this locality?

3. How do you assess the capacity of the specific tourism infrastructure to support tourism?

4. What do you think is the report (compare) between the prices practiced by the travel agents, service providers and services Care?

Hypothesis 2 5. Do you consider that the tourist activity in your local area is damaging the natural environment?

6. Do you appreciate the diminution of the originality and authenticity of local cultural landscapes following the intensification of the tourist phenomenon?

7. How do you look at the connection between the local community and the tourists?

8. Does the local public authority promote and encourage community involvement in tourism planning?

9. Is the local public authority able to strike a balance between the needs of

Hypothesis3 the community, the benefits and a quality tourism process?

10. Do you think that the local community benefits from the tourist phenomenon?

11. Do you think that local authorities should be more involved in this process to increase the income of the zone?

Hypothesis $4 \quad 12$. Is tourism a safe labor market?

13. Do you think that tourism represents the economic future of the locality?

14. Has the quality of life increased in the locality as a result of its tourist development?

15. Do you think that the local public institutions in Moroieni have so far implemented projects for attracting funds to the tourism segment?

16. How do you appreciate the support received from local authorities for obtaining permits, permits and other documents necessary for the development of tourist activity?

17. What possible changes could be made by local government to improve the efficiency of the tourism process?

18. How effective do you think is the tourist promotion of local attractions through current initiatives/actions made?

Table1. Questionnaire design

\section{Results and discussions}

The analysis of the data obtained through the interpretation of the results shows differences between the perceptions of the two types of subjects regarding the role and involvement of the public authority in the tourism process. Their attitude to the subject under discussion is positive and appears unambiguously among all participants in the research. 
The primary analyzed data addresses the social attributes of the respondents.

\begin{tabular}{|c|c|c|c|c|c|c|}
\hline \multirow{2}{*}{$\begin{array}{l}\text { Demographic } \\
\text { attribute }\end{array}$} & \multirow[t]{2}{*}{ Category } & \multicolumn{2}{|c|}{ Percent \% } & \multirow{2}{*}{$\begin{array}{l}\text { Demographic } \\
\text { attribute }\end{array}$} & \multirow[t]{2}{*}{ Category } & \multirow{2}{*}{$\begin{array}{c}\text { Percent } \\
\%\end{array}$} \\
\hline & & Tourist & Resident & & & \\
\hline \multirow[t]{3}{*}{ Gender } & Male & 57 & 41 & How many years & $5-15$ & 18 \\
\hline & & & & residing in & $15-25$ & 11 \\
\hline & Female & 43 & 59 & $\begin{array}{l}\text { Moroieni? } \\
\text { (only resident) }\end{array}$ & $>25$ & 71 \\
\hline \multirow[t]{5}{*}{ Age } & $15-25$ & 17 & 14 & \multirow{5}{*}{$\begin{array}{l}\text { Do you work } \\
\text { into the } \\
\text { tourism } \\
\text { sector? } \\
\text { (only resident) }\end{array}$} & & 13 \\
\hline & $25-35$ & 29 & 34 & & Yes & \\
\hline & $35-45$ & 48 & 38 & & No & 87 \\
\hline & $45-60$ & 6 & 11 & & & \\
\hline & $>60$ & 0 & 3 & & & \\
\hline \multirow[t]{3}{*}{ Qualification } & high school & 32 & 48 & \multirow[t]{3}{*}{$\begin{array}{l}\text { Way of travel } \\
\text { (only tourists) }\end{array}$} & single & 26 \\
\hline & $\begin{array}{l}\text { post- } \\
\text { secondary } \\
\text { education }\end{array}$ & 16 & 29 & & $\begin{array}{l}\text { with the } \\
\text { family } \\
\text { (3-5 persons) }\end{array}$ & 63 \\
\hline & $\begin{array}{l}\text { higher } \\
\text { education }\end{array}$ & 52 & 33 & & $\begin{array}{l}\text { group larger } \\
\text { than } 5 \text { people }\end{array}$ & 11 \\
\hline \multirow[t]{3}{*}{$\begin{array}{l}\text { Marital } \\
\text { status }\end{array}$} & single & 49 & 21 & \multirow{3}{*}{$\begin{array}{l}\text { You have visited } \\
\text { this area? } \\
\text { (only tourists) }\end{array}$} & $\begin{array}{l}\text { for the first } \\
\text { time }\end{array}$ & 38 \\
\hline & married/ & 51 & 79 & & second time & 41 \\
\hline & cohabiting & & & & $\begin{array}{l}\text { more than } \\
\text { twice }\end{array}$ & 21 \\
\hline
\end{tabular}

Table 2. Demographics

Analysis of the questionnaire allowed the validation or refutation of hypotheses.

Question 1 highlights the main tourist attraction of the area of Moroieni. The highest percentage, both for the locals and the tourists, 73 respectively 81 , was attributed to the Bucegi Natural Park, followed by the cultural manifestations (16 and 10), the traditional element (11 and 2). $7 \%$ of people surveyed among locals responded with "do not know", which denotes a certain indifference or ignorance of these issues. These answers also relate to the second question, meaning tourism types that can be practiced: rest and recreation tourism (44\%, 42\%), ecotourism (23\%, 18\%), and agrotourism (14) \%, $13 \%)$; cultural tourism $(7 \%, 12 \%)$, religious tourism (7\%, $9 \%)$, other forms (3\%, $6 \%)$. It is noticed that the emphasis is mainly on capitalizing on the natural heritage, and the responses are sensibly similar. However, it is worth noting the 
differences that suggest a local preference for eco and agrotourism, forms that involve more the local community and, in the longer term, the punctual cultural and short-term manifestations, more appreciated by tourists. The capacity to support specific tourism infrastructure is viewed differently from the two categories. The locals consider that tourism-specific infrastructure is sufficiently developed in the situation of tourist traffic growth (87\%), while tourists consider it insufficiently developed (73\%). Nevertheless, the ratio between the quality of services and their price is competitive compared to other tourist locations, being appreciated as satisfactory by $75 \%$ of the locals and $67 \%$ of the tourists.

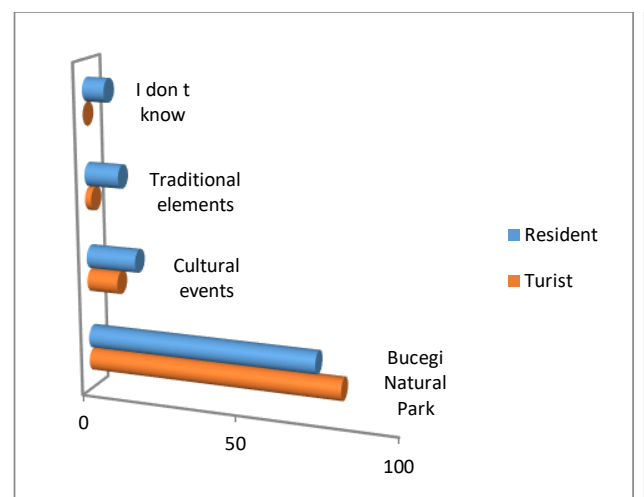

Figure 1. Landmarks

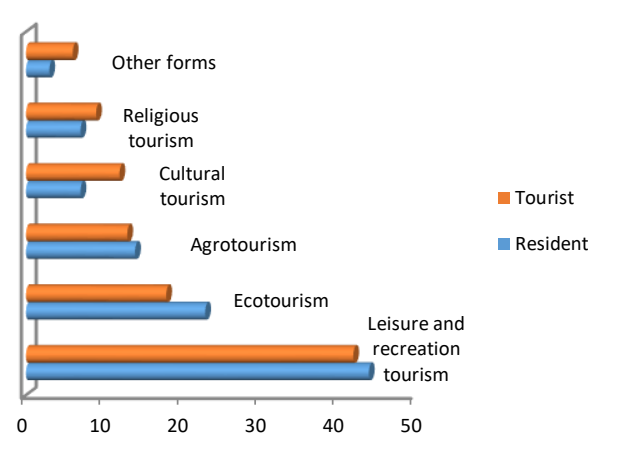

Figure 2. Formes of tourism

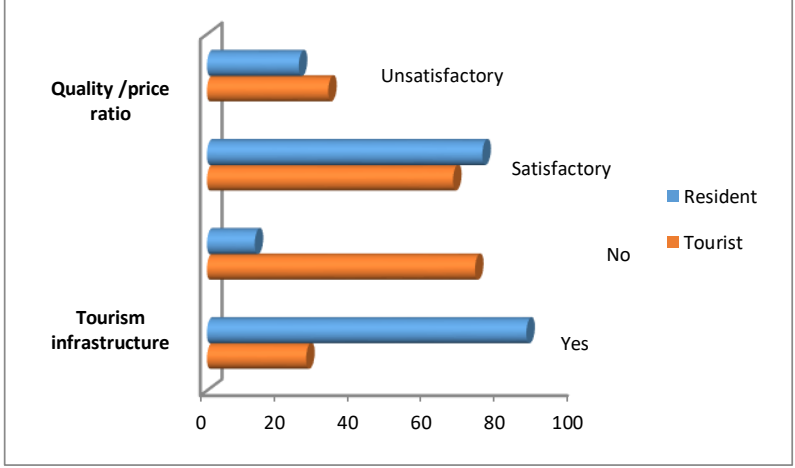

Figure 3. Tourism infrastructure and quality/price ratio

Analyzing these answers, we consider the first hypothesis to be valid, meaning that Moroieni is a favorable area to tourism development.

The tourist attractiveness of the area is enhanced by a large spatial concentration of the tourist potential that allows tourism to be practiced throughout the year. Framed in part by a protected natural area - the Bucegi Natural Park, with their own conservation and protection policies, these objectives are not under the direct authority of the local public authority 
Moroieni. In the same situation are many of the monument buildings, which belong to the patrimony of other public institutions (Museum of Romanian Literature Bucharest, Târgovişte County Emergency Hospital), or are private properties. Involvement of local public authorities can be found only at the level of efficient collaboration with the mentioned institutions in order to ensure their functionality and their capitalization as constituents of the local natural and cultural landscape. Making sustainable tourism involves minimizing adverse effects on these landscapes, and local communities can intervene by developing local conservation and conservation strategies through greening, education and information.

In this context, the answers to questions $\mathbf{5}$ and $\mathbf{6}$ could be clearly distinguished: the tourist activity does not have a negative impact on the environment (tourists - $89 \%$, residents - $43 \%$ ) and does not alter the authenticity of the local cultural landscape (tourists - 87\% - 83\%) either. The logic of the answers lies in the longterm vision of the two categories on the environment by reference to it as at home/welfare - the residents or the product - the tourists. The positive impact of degradation of the natural and anthropic environment as a whole implies the assumption of hidden responsibilities of motivations such as the tourist is always/never guilty! In this case, the role of local authorities is to intervene by creating systems for the collection and recycling of landfills adapted to the environment and activity (festivals, camping, sports competitions), or developing packages specific to ecological niche tourism (e.g.speotourism).

Defining sustainable tourism on the same footing is the locals and the traveler. Questions 7 and 8 are complementary, meaning the link between the local community and the tourists is good (tourists - 93\%, residents - 76\%) and is mediated through local public authorities which according to the analyzed answers encourage the involvement of the community/locals in touristic planning (tourists - 87\%, residents - 71\%). The analysis of question 9 can also provide clarification on the negative answers of local people to previous questions ( $23 \%$ and $29 \%$ respectively). Here both locals and tourists consider that local public authority cannot balance the needs of the community, benefits and a quality tourism process $(61 \%, 71 \%)$ because there are a multitude of problems that cannot be fully managed and one of the participants in this equation will have dissatisfaction. However, the role of the local authority of equilibrium is recognized $(39 \%, 29 \%)$, and the constant efforts of this entity are appreciated positively by all respondents. 


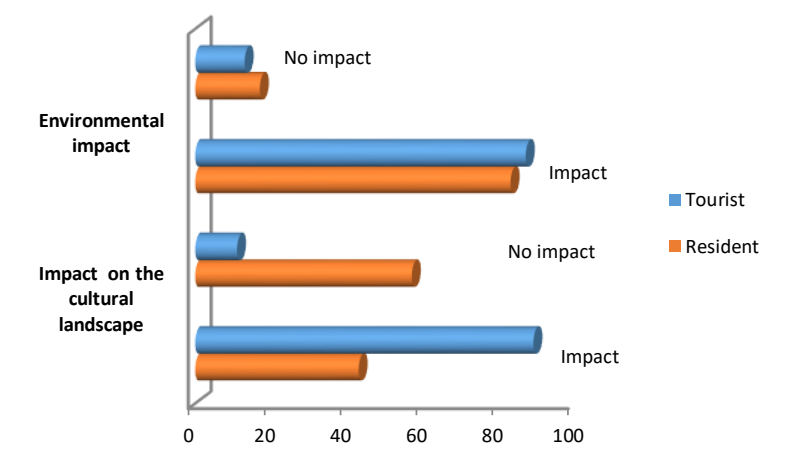

Figure 4. The impact of tourism on the natural and cultural landscape

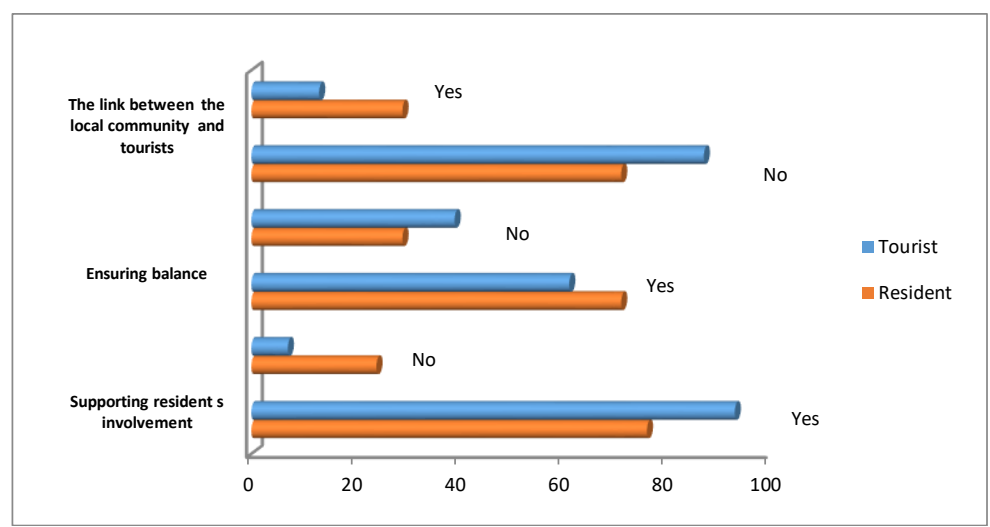

Figure 5. Residents-Public authority-Tourists

Hypothesis 2 is validated.

Question 10. 63\% and 89\% of the respondents (residents and tourists) consider that the community benefits from the tourist phenomenon and $37 \%$ and $11 \%$ respond negatively. By correlating the responses of the two categories, those with the affirmative answer list the following benefits for the community: $93 \%$ consider the maintenance of the roads as a main benefit, followed by the tourist activity revenues (7\%). The negative reasons for lack of benefits are: minimal involvement or lack of involvement of local people in this process (58\%), low access of local people to revaluation of tourism patrimony (21\%), lack of direct income from this process of local public administration/citizen (17\%); others (4\%) where the respondents added the limited access to the Bucegi Natural Park, untaxed tourist activities by the local community. These responses are linked to the following question, $\mathbf{1 1}$ where local authorities are expected to become more involved in income-generating activities $(41 \%$ locals have answered no) or at least continue the upward trend reported in recent years 
(59\% locals answered yes). In the case of tourists who may have perceived this involvement, by increasing prices for various services, the introduction of new taxes, the response rates are just the opposite $-88 \%$ no, $12 \%$ yes.

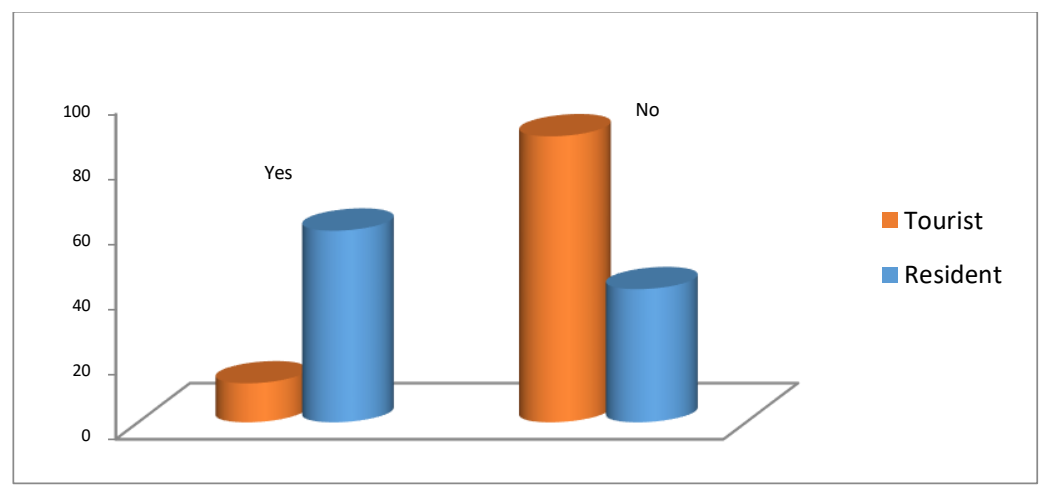

Figure 6. Implication of authorities in increasing tourism revenues

Tourism is one of the most dynamic sectors of the local economy. The activity of tourism has a layered structure and is manifested on a multitude of plans that cover the whole socio-cultural and economic ensemble that targets a community. Stimulating economic growth in communities that properly identify and manage tourism resources is seen in the emergence of new jobs. In the case of Moroieni, the emergence of new jobs does not mean also the occupation of the existing free employment. According to INSS, only 23 people work in the field of tourism services, the causes of which are family affairs or financial motivation. Preserved and administered fairly and rationally, tourist resources are virtually inexhaustible. Doubled by the permanent motivation of the tourist, they can represent the economic future of any locality. The major opportunity that the tourism potential can offer by developing complex tourist product offers is, at the level of the local communities, increasing the quality of life by improving the living conditions.

The answers to questions $\mathbf{1 2}, \mathbf{1 3}, \mathbf{1 4}$ support these statements. Therefore, $86 \%$ of the locals and $92 \%$ of the tourists consider tourism a safe job market, agreeing about the same percentage ( 83 and 84 respectively) with the fact that it represents the economic future of the locality. Direct engagement in a viable tourism process results in an increase in the quality of life as certified by 75 percent of tourists and 69 by local respondents. Raising quality of life implies, besides financial stability, environmental conditions and adequate socio-cultural framework. The total or partial lack of one of these parameters led to a $25 \%$ or $31 \%$ negative response. 


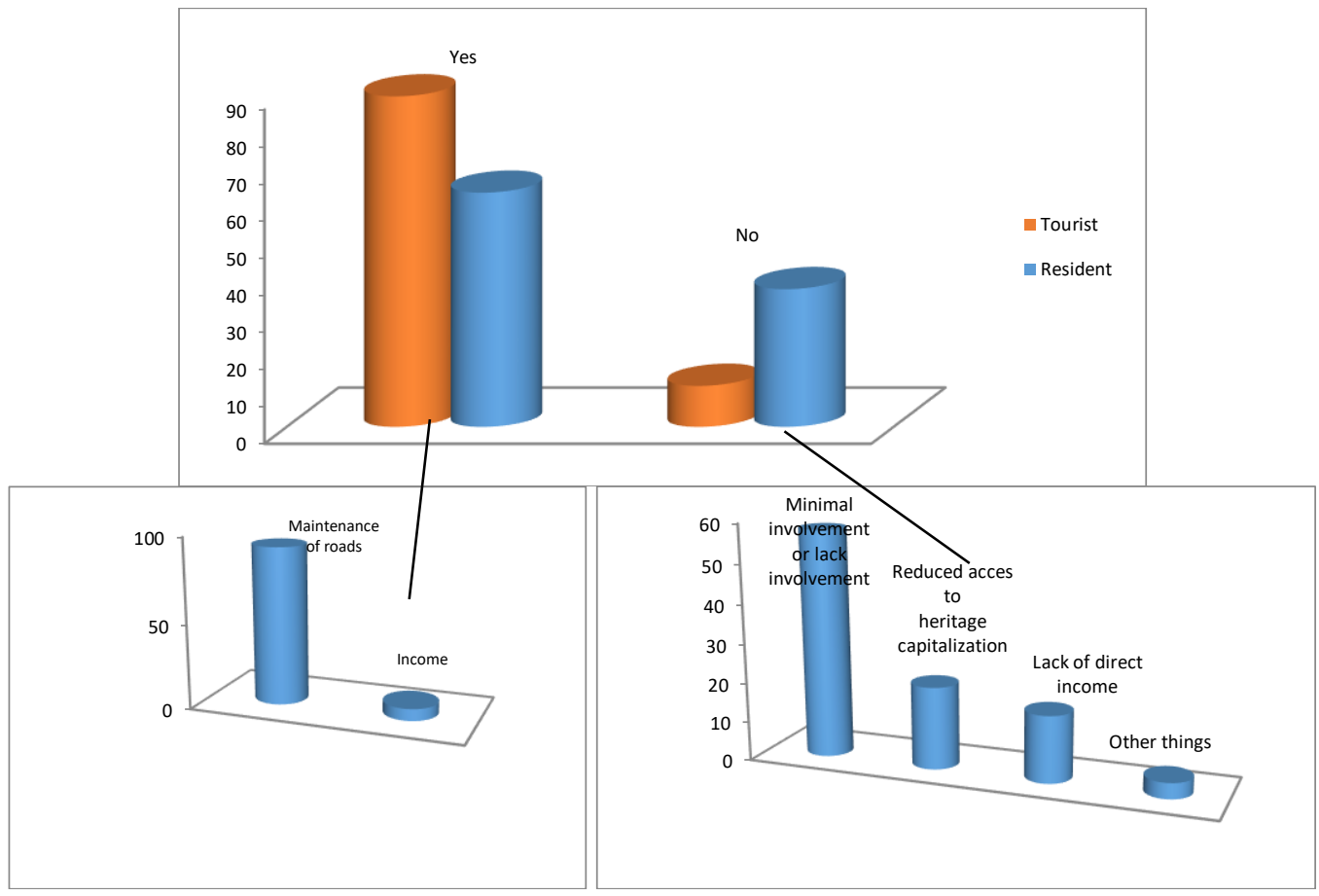

Figure 7. Local community and the benefits of tourism. Benefits and impediments.

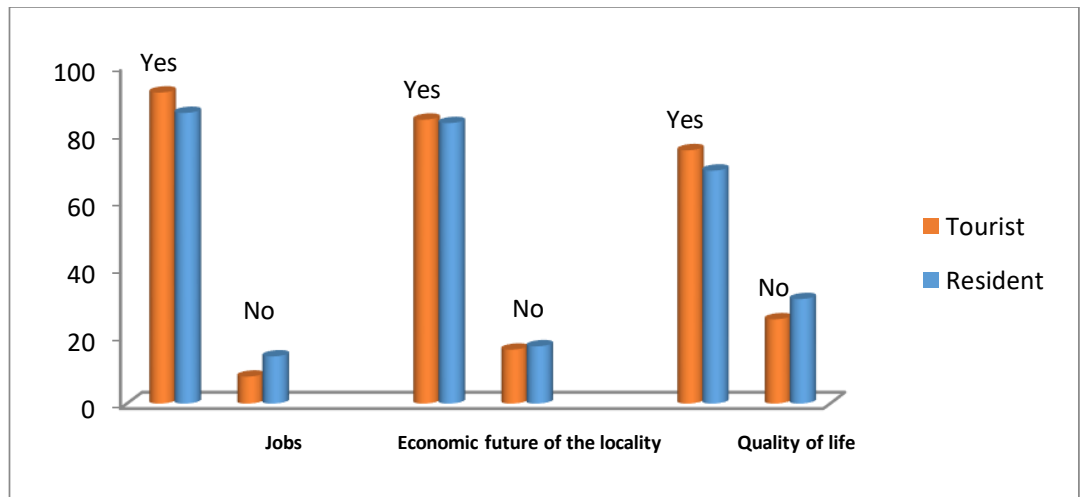

Figure 8. Tourism and quality of life

The overall analysis of these results confirms the third hypothesis.

The active involvement of local authorities in Moroieni in the tourism process results from the interpretation of the answers to the following questions.

At question 15 36\% tourists and 30\% residents responded positively, without being able to appoint such a project; $12 \%$ and $17 \%$ answered no, and $42 \%$ and $43 \%$ responded that they did not know about the implementation of tourism projects. Question 16 provides somewhat contradictory answers - 69\% of tourists 
and $72 \%$ of residents believe that they have received support from the authorities, although only $7 \%$ of tourists said they turned to the local authority and only $13 \%$ of the locals are directly related to the process tourism. Enhanced tourism visibility through promotional activities/initiatives is one of the elements targeted by tourists and residents in the active involvement of authorities in the tourism process. In question 18, most respondents consider the promotion by authorities (76\% - tourists, 59\% - residents) lacking a local cultural agenda, poor communication between tenderers and the public, lack of coordinated information and promotion strategies at regional and national level. The central element that led to positive responses ( $24 \%$ and $41 \%$ respectively) was the existence of tourist information centers (Runcu-Pietroşiţa-Moroieni Tourism Information Center). Along with promotion, in question 17, the changes made by the public administration are aimed at: supporting agrotourism (36\%); improvement of leisure infrastructure (28\%), promotion (22\%), preservation and consolidation of identity (14\%).

Hypothesis 4 is partially validated.

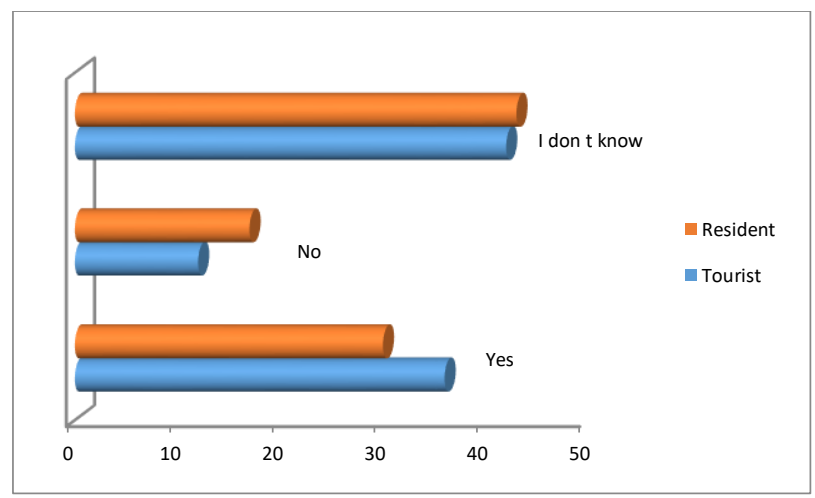

Figure 11. Projects in the field of tourism

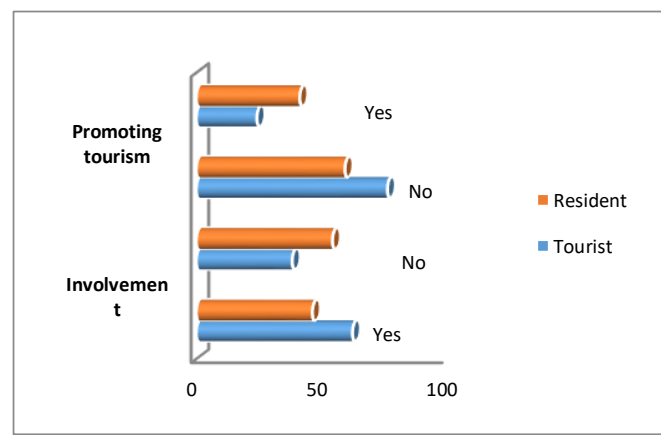

Figure 12. Local authorities involvement.

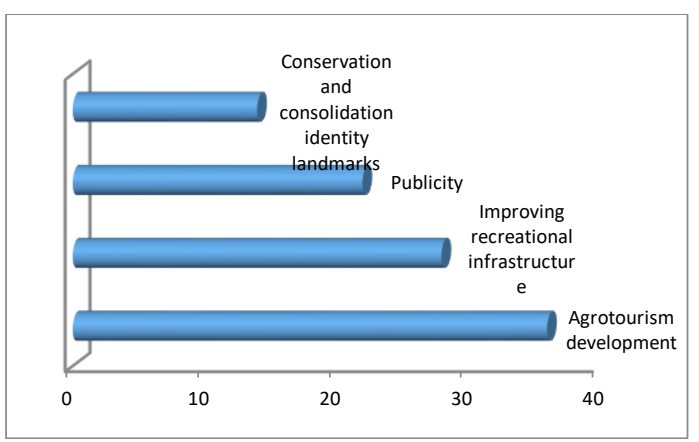

Figure 13. Directions of change 


\section{Conclusions}

The local community plays an important role in optimizing the local tourism process. The stimulation and interest of the local community in the development of complex, flexible, viable tourist products represent the main role of public administration in the tourism process. In the context of current Romania, this role is undermined by the lack of a coherent strategy in the field of promoting and capitalizing on the local tourism potential, lack of financial support, staffing and qualification. The analysis of the perception and attitude of local people and tourists on the active involvement of local authorities in the tourism phenomenon is a credible starting point, well anchored to reality, for tourism planning meant to provide products that satisfy all the actors involved. At the same time, this is the support for local tourism projects and initiatives. As a link between the local community and tourist, the local public authority is the guarantor of the balance between the needs of the community, benefits and a quality tourism process.

\section{References}

[1] Ahmed, F., Moodley, V., Sookrajh, R. (2008). The environmental impacts of beach sport tourism events: a case study of the Mr Price Pro Surfing Event, Durban, South Africa. Africa insight, 38(3). Pp. 73-85.

[2] Alessa, L., Bennett, S.M., Kliskey, A.D. (2003). Effects of knowledge, personal attribution and perception of ecosystem health on depreciative behaviours in the intertidal zone of Pacific National Park and Reserve. Journal of environmental management, 68(2). pp.207-218.

[3] Ap, J. (1992). Residents' perceptions on tourism impacts. Annals of Tourism Research, 19(4), pp. 665-690.

[4] Brida, J.G., Disegna, M., Osti, L., 2014,Residents' Perceptions Of Tourism Impacts And Attitudes Towards Tourism PoliciesTourismos: An International Multidisciplinary Journal of Tourism, 9(1), pp. 37-71.

[5] Brunt, P., Courtney, P. (1999). Host Perceptions of Sociocultural Impacts. Annals of Tourism Research, 26(2), pp. 493-515.

[6] Chiţescu, M. (2003). Substratul geologic-factor al potenţialuluituristicînjudeţulDâmboviţa, The Annals of Valahia University of Târgoviste, Geographical Series, 3, pp. 345-352.

[7] Del Chiappa, G., Presenza, A. (2011). Tourist Destination and network's analysis approach. An empirical study on Costa Smeralda-Gallura. In Proceedings of The 2011 AthensTourism Symposium, 2-3 February, Athens, Greece.

[8] Diedrich, A., García-Buades, E. (2009). Local perceptions of tourism as indicators of destination decline. Tourism Management, 30(4), pp. 512-521.

[9] Dimitrakopoulos, P. G., Jones, N., losifides, T., Florokapi, I., Lasda, O., Paliouras, F., Evangelinos, K.I. (2010). Local attitudes on protected areas: Evidence from three Natura 2000 wetland sites in Greece. Journal of EnvironmentalManagement, 91(9),pp.1847-1854

[10] Dogan, H. (1989). Forms of Adjustment: Sociocultural Impacts of Tourism. Annals of Tourism Research, 16, pp.216-236.

[11] Erdeli, G.,Gheorghilaş, A. 2006, Amenajărituristice. București:EdituraUniversitară. 
[12] Fredline, E., Faulkner, B. (2000). Host community reactions: a cluster analysis. Annals of Tourism Research, 27(3). pp. 763-784.

[13] Gu, M., Wong P.P. (2006). Residents' Perception of Tourism Impacts: A Case Study of Homestay Operators in Dachangshan Dao, North-East China, Tourism Geographies. 8(3). pp. 253-273.

[14] Jones, N., Panagiotidou, K., Spilanis, I., Evangelinos, K.I., Dimitrakopoulos, P.G.( 2011). Visitor's perceptions on the management of an important nesting site for loggerhead sea turtle (CarettaCaretta L.): The case of Rethymno coastal area in Greece. Ocean and Coastal Management, 54, pp.577-584.

[15] Lankford, S.V., Howard, D.R. (1994). Developing a Tourism Attitude Impact Scale. Annals of Tourism Research, 24 (1), pp.121-139

[16] Liu, J., Ouiyang, Z., Miao, H. (2010). Environmental attitudes of stakeholders and their perceptions regarding protected area-community conflicts: A case study in China. Journal of Environmental Management, 91, pp.2252-2262.

[17] Ozturk, A., Saglam, B., Barli, O. (2010). Attitudes and perceptions of rural people towards forest protection within the scope of participatory forest management: A case study from Artvin, Turkey. African Journal of Agricultural Research, 5(12), pp. 1399-1411.

[18] Pehoiu, G., Murărescu, O., Frînculeasa, M. (2014). The cultural-historical sites of Târgoviște Municipality and its surroundings and their touristic attractiveness, International Multidisciplinary Scientific Conferences on Social sciences and Arts (SGEM2014 Conference Proceedings), 3, Economics and Tourism, pp. 573-580.

[19] Petrosillo, I., Zurlini, G., Corliano, M.E., Zaccarelli, N., Dadamo, M. (2007). Tourist perception of recreational environment and management in a marine protected area. Landscape and Urban Planning, 79, pp. 29-31.

[20] Presenza, Del Chiappa,G, Sheehan, L. (2016)Residents'Engagement and Local Tourism Governance in Maturing Beach Destinations: Evidence from an Italian Case Study Tourism Travel and Research Association: Advancing TourismResearch Globally. 14.

[21] Priskin, J. (2003). Tourist perceptions of degradation caused by coastal nature-based recreation. Environmental management, 32(2), pp. 189-204.

[22] Sebastian L.M. and Rajagopalan P. (2009). Socio-cultural transformations through tourism: a comparison of residents' perspectives at two destinations in Kerala, India. Journal of Tourism and Cultural Change, 7(1),pp.45-56

[23] Simmons, D.G. (1994). Community participation in tourism planning. Tourism Management, 15(2), pp. 98-108.

[24] Suckall, N., Fraser, E.D.G., Cooper, T., Quinn, C (2009). Visitor perceptions of rural landscapes: A case study in the Peak District National Park, England. Journal ofEnvironmental Management,90,pp.1195-1203.

[25] Szell, A. B., (2012) Attitudes and Perceptions of Local Residents and Tourists Toward the Protected Area of Retezat National Park, Romania. Master's Theses. Paper 59.

[26] Van Winkle, C.M., Mackay, K.J. (2008). Self-serving bias in visitors' perceptions of the impacts of tourism. Journal ofleisure research, 40(1), pp.69-89.

[27] Vargas-Sanchez, A., Porras-Bueno, N., Plaza-Mejia, M. (2011). Explaining residents' attitudes to tourism. Is a universal model possible?. Annals of Tourism Research, 38(2), pp. 460-480.

[28] Wall, G., A. Mathieson (2006). Tourism: change, impacts and opportunities. Pearson Prentice Hall,Essex. 